\title{
The influence of the conservation status and changes in the rainfall regime on forest-savanna mosaic dynamics in Northern Brazilian Amazonia
}

\author{
Fabiana R. COUTO-SANTOS ${ }^{*}$, Flávio J. LUIZÃO ${ }^{1}$, Arnaldo CARNEIRO FILHO² \\ 1 Instituto Nacional de Pesquisas da Amazônia (INPA) / The Large Scale Biosphere-Atmosphere Experiment in Amazonia (LBA). Av. André Araújo, 2936, Aleixo, CEP: 69060-000. \\ Manaus, Amazonas, Brazil. couto.santos2@gmail.com, fluizao@inpa.gov.br \\ 2 Secretaria de Assuntos Estratégicos da Presidência da República (SAE-PR). Esplanada dos Ministérios - Bloco 0 - $8^{\circ}$ andar, CEP: 70052-900, Fone: (61) 3411-4645. Brasília, \\ DF, Brazil. arnaldo.carneiro@presidencia.gov.br \\ *Corresponding Author: couto.santos2@gmail.com
}

\begin{abstract}
Coupled carbon/climate models are predicting changes in Amazon carbon and water cycles for the near future, with conversion of forest into savanna-like vegetation. However, empirical data to support these models are still scarce for Amazon. Facing this scenario, we investigated whether conservation status and changes in rainfall regime have influenced the forest-savanna mosaic over 20 years, from 1986 to 2006, in a transitional area in Northern Amazonia. By applying a spectral linear mixture model to a Landsat-5-TM time series, we identified protected savanna enclaves within a strictly protected nature reserve (Maracá Ecological Station - MES) and non-protected forest islands at its outskirts and compared their areas among 1986/1994/2006. The protected savanna enclaves decreased $26 \%$ in the 20 -years period at an average rate of 0.131 ha year $^{-1}$, with a greater reduction rate observed during times of higher precipitation, whereas the non-protected forest islands remained stable throughout the period of study, balancing the encroachment of forests into the savanna during humid periods and savannization during reduced rainfall periods. Thus, keeping favorable climate conditions, the MES conservation status would continue to favor the forest encroachment upon savanna, while the non-protected outskirt areas would remain resilient to disturbance regimes. However, if the increases in the frequency of dry periods predicted by climate models for this region are confirmed, future changes in extension and directions of forest limits will be affected, disrupting ecological services as carbon storage and the maintenance of local biodiversity.
\end{abstract}

KEYWORDS: Spectral linear mixture model, ecotone, savannization, climate change, protected areas.

\section{Influência do status de conservação e da variação da precipitação na dinâmica de mosaicos floresta-savana ao norte da Amazônia Brasileira}

\begin{abstract}
RESUMO
Modelos acoplados carbono/clima prenunciam mudanças nos ciclos do carbono e da água em um futuro próximo, substituindo gradualmente florestas tropicais por savanas. No entanto, dados empíricos que dão suporte a estes modelos ainda são escassos para a Amazônia. Diante deste cenário, investigamos se o status de conservação e as variaçóes de precipitação influenciaram as mudanças ocorridas em 20 anos nos mosaicos floresta-savana, em uma área de transição ao norte da Amazônia. Utilizando imagens-fração do modelo de mistura aplicado à série temporal Landsat-5TM, enclaves de savana protegidos da Estação Ecológica de Maracá e ilhas de mata não protegidas do seu entorno foram identificados e suas áreas comparadas entre os anos 1986, 1994 e 2006. Os enclaves protegidos contraíram 26\% em 20 anos a uma taxa média de 0,131 ha ano ${ }^{-1}$, com maiores taxas de retração em períodos de maior precipitação. As ilhas de mata não protegidas permaneceram estáveis no período total amostrado, porém com avanço de florestas sobre savanas em períodos mais úmidos e savanização em períodos mais secos. Mantendo-se as condições climáticas favoráveis, o status de conservação da Estação Ecológica Maracá continuará favorecendo o avanço de florestas e as áreas não protegidas permanecerão resilientes aos distúrbios. Porém, confirmada a tendência de aumento da frequência de eventos climáticos de seca prevista pelos modelos climáticos para essa região, a extensão e direção de mudanças futuras dos limites florestais seráo afetadas, comprometendo os serviços ecológicos como a estocagem de carbono e a manutenção da biodiversidade local.
\end{abstract}

PALAVRAS-CHAVE: Modelo mistura espectral, ecótono, savanização, mudanças climáticas, áreas protegidas. 


\section{INTRODUCTION}

Much of the seasonal tropics are composed of mosaics of savanna vegetation and forests. Several factors have been identified responsible for the transition between these two vegetation types, including climate, fire regime, changes in land use, soil water availability, and herbivory, as well as edaphic and paleoenvironmental factors (Furley and Ratter 1990; Sankaran et al. 2004). Coupled carbon/climate models foreshadow changes in the carbon and water cycles in the near future resulting in the gradual replacement of tropical forests with savanna vegetation in Amazonia (Oyama and Nobre 2003; Salazar et al. 2007). These changes are especially expected to occur in the eastern and southern limits of the basin induced by disturbances (Sternberg 2001), while the Hylean region is thought to be relatively stable (Hirota $e t$ al. 2010). The presence of protected areas can be effective in reducing the likelihood of savannization in the Amazon (Soares-Filho et al. 2010).

Medium to high spatial resolutions remote sensing has the potential to map the extent of and changes to the vegetation cover using multi-temporal image sequences. The reflectance mixture within a single pixel of a Landsat-5-Thematic Mapper (TM) image is common in heterogeneous environments and occurs due to the limitations in spatial resolution, the complexity of vegetation structure, and the high abundance of plant species, which make it difficult to classify these environments using traditional methods, both in savanna areas and in the Amazon forest (Lu et al. 2003; Ferreira et al. 2007). The use of spectral linear mixture models (SLMM) captures this sub-pixel variation, and seems promising when used for vegetation classification and biomass estimation, for detecting changes in land use and land cover, and for the mapping and monitoring of burned, deforested, and mined areas in the Amazon (Lu et al. 2003; Anderson et al. 2005; Shimabukuro et al. 2010). SLMM applications have demonstrated high performance in determining areas of Amazonian savannas in the forest-savanna boundary regions in the State of Roraima and in other areas of Cerrado (Brazilian savanna type) in central Brazil, although it is still difficult for the model to classify the specific sub-classes of this vegetation (Ferreira et al. 2007).

In the current paper, we investigated the extent, type, and causes of vegetation changes that have occurred in the protected savanna enclaves of the Maracá Ecological Station (MES) and in the forest islands in the unprotected areas surrounding it in a transition region in Roraima, northern Brazilian Amazonia. By comparing a 20-year time series (1986-2006) of fraction images, derived from a mixture model applied to a Landsat-5-TM time series, and analyzing the long-term precipitation trends of the region, we aimed to accomplish the following: (1) to quantify the rates of change (contraction/expansion) for the forest and savanna vegetation in the region; and (2) to determine whether climatic factors and conservation status influenced this dynamic.

\section{MATERIALS AND METHODS}

\section{Study Area}

The study area was the Maracá Ecological Station, hereafter referred to as "MES", and its immediate surroundings (an approximately $80 \mathrm{~km}$ radius). Formed by a bifurcation of the Uraricoera river in the Furo Santa Rosa and Maracá (Figure 1 ), the MES is a 101,312 ha protected area (fully protected at the federal level), with no record of fire and/or human impacts since its inception in 1978. The area is located on an obvious biogeographic and climatic division, with the Amazonian rainforests to the west and the savanna plains to the east forming part of the mosaic of open vegetation ecosystems known as the "Rio Branco-Rupununi" savanna complex (Figure 1). The MES is located at a transition in the humid tropical climate, from the savanna subtype (Aw) to the monsoon subtype (Am), with marked seasonality; the dry season runs from October to March, and the rainy season from April to September (Thompson et al. 1992b).

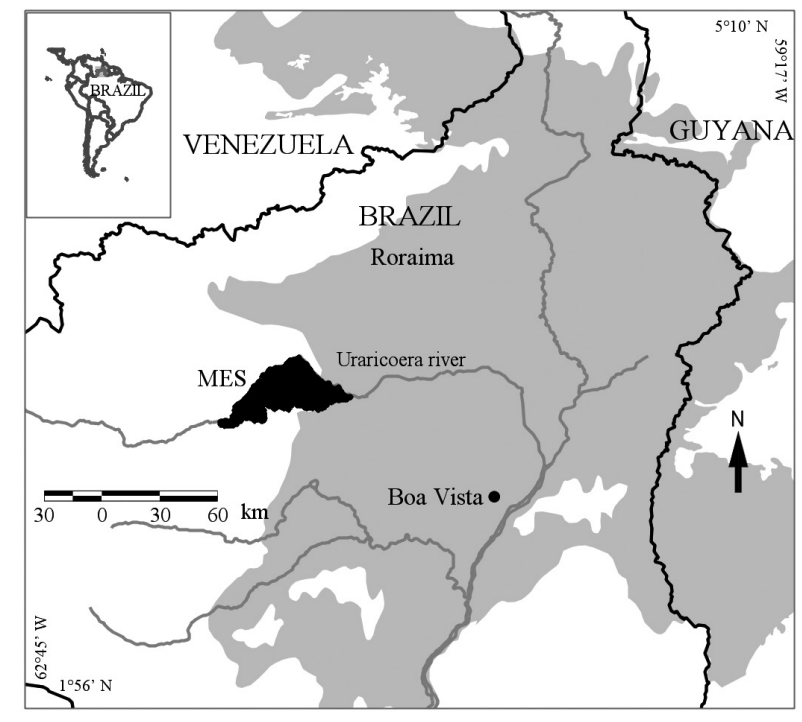

Figure 1 - Location of the Maracá Ecological Station (MES) on the biogeographic and climatic division in northern Amazonia. The Guyana savanna ecoregion in grey.

The MES is divided across two Landsat scenes, with the western two-thirds covered by point-orbit 233-58 and the eastern third by 232-58. Approximately $60 \%$ of the scene that includes the eastern part of the MES is composed of open cover types. The MES area consists of $84 \%(85,000$ ha) forest and approximately $15 \%$ non-forest vegetation, $6 \%$ of which are savanna enclaves that occur in significantly 
higher proportions in its eastern portion (Furley et al. 1994); two ecological types of savanna are recognized: (1) seasonal savannas, which are influenced only by the prolonged water shortage during the dry season; and (2) hyperseasonal savannas, which are influenced by both the scarcity and excess of water that occurs annually during the dry and rainy seasons, respectively.

\section{Remote sensing and pre-processing data}

Three Landsat-5-TM scenes (point orbit 232-58), acquired during the dry season, were selected: in February 1986, in February 1994, and in April 2006 (April was included as a dry month as the rainfall was below expected amounts in 2006); each image had a spatial resolution of 30 meters, high quality, and a low percentage of cloud cover.

The selected images were geometrically corrected with an accuracy of 0.2 pixels, applying a first-degree polynomial (affine) rectification algorithm and a nearest neighbor resampling method. The scene from 2006 was converted to a Universal Transverse Mercator (UTM) system based on the ortho-rectified NASA-GeoCover-2000 and was used as a reference to co-register the images from the other years. The three scenes were cropped to the coordinates $660211.452 \mathrm{~W}$ and $405496.430 \mathrm{~N}$, and $750432.968 \mathrm{~W}$ and $344748.134 \mathrm{~N}$, providing a total study area of $5,480.80 \mathrm{~km}^{2}$. The preprocessed images were exported, with the projection UTM $20 \mathrm{~N}$ and datum WGS84, for the implementation of digital image processing using the SPRING software (http://www.dpi. inpe.br/spring).

\section{Digital image processing}

A SLMM, based on the weighted least squares method, was applied using bands 3, 4, and 5 of the Landsat-5-TM scenes. To determine the fraction images of vegetation, soil, and shade, three endmembers were separately selected directly from the image scenes for each year. Due to the ability of fraction images to detect small changes in coverage area over a given time interval (Haertel et al. 2004), the soil fraction image was chosen to detect natural variations in the small savanna enclaves present in the MES and in the fraction of vegetation in the forest islands surrounding the MES.

The chosen fraction images of the SLMM were then passed through a digital classification to determine the forest and non-forest areas of interest, based on image segmentation procedures, unsupervised classification, and post-classification editing methods commonly applied in studies of land cover changes. The region growing segmentation algorithm was used, with thresholds of similarity and area of 30 and 2, respectively (Almeida-Filho and Shimabukuro 2002). These thresholds were defined, after several experimental iterations, as those that best characterized the forest and savanna areas. For the classification of regions, an unsupervised clustering algorithm (ISOSEG) was applied, with thresholds of $75 \%$ and 99\% for shade and vegetation fraction images, respectively.

From the clusters generated by the classification of regions, two savanna classes were defined for the MES and one forest class was defined for its surroundings. Although the classifier identified the two classes of savanna present in the MES, it did not faithfully represent the features displayed on the ground; therefore, these two classes were merged into a single savanna class. Cover polygons were derived from a final matrix edition, based on a visual analysis comparing the classified areas with a color composite of the original images and a Quickbird image. The classification accuracy was evaluated by comparing the results of the classification map generated automatically with those produced by visual interpretation, as proposed by Almeida-Filho and Shimabukuro (2002).

As an end result of these processes, it was possible to identify and accurately locate the savanna polygons (enclaves) present within the MES and the forest polygons (forest islands) in its surroundings.

\section{Multi-temporal analysis}

The area (in ha) of all savanna enclaves detected was calculated for each scene from each year. To evaluate the dynamics that occurred due to the natural variations in the forest islands, areas where deforestation was detected from 1997 to 2006, using the "Program for calculation of Amazon deforestation" (PRODES Project - available at http://www. obt.inpe.br/prodes), were excluded, and only those islands greater than 5 ha were considered to ensure accuracy at the scale chosen $(1: 50,000)$ for the surrounding areas.

To evaluate the changes in both the savanna enclaves within the MES and in its surrounding forest islands over the 20 years selected, a multi-temporal analysis comparing the total area of the polygons over the years was developed, using a non-parametric analysis of variance Kruskal-Wallis (KW), followed by a multiple comparison test. Histograms of the distribution of polygon size classes in the different years were compared using the chi-square test $\left(\chi^{2}\right)$, at a significance level of $95 \%$. Classes with expected frequencies of less than 5 were combined to avoid bias in the analysis.

The rate of change (contraction/expansion) for each area over 20 years was calculated based on the difference in the total area of each polygon between the years 2006 and 1986. Rates of partial change were also calculated for different sampling periods (1994-1986 and 2006-1994) and compared using the nonparametric paired Wilcoxon test (V). Positive changes in the rates of change were characterized as the enclaves/islands expanding, while negative and zero changes represented contraction and stability, respectively. 


\section{Rainfall data}

To investigate the long-term climate trends in the region, rainfall data from 1910 to 2008 were compiled from the climatological station of Boa Vista/RR. This station was chosen because it is the only station from this Brazilian State with data covering a long time series, providing a more robust climate trend analysis, and because it is representative of the climate of the areas characterized by the surrounding savanna matrix. However, for an analysis of the climate in the forest matrix areas, data available from 1986 to 2010 were also compiled from the meteorological station located at the MES. Missing data from the Boa Vista station (from 1916 to 1922, 1957 to 1960 , and 1962 to 1965 ) and from the MES (1994, 1995 ) were not considered in the analysis.

An analysis of linear trend, fitted to the equation $\boldsymbol{P}=\boldsymbol{P}_{0^{+}}$ $\boldsymbol{a t}$, was applied to the rainfall data time series, where $\boldsymbol{a}$ is the slope of the line that indicates the magnitude and direction of change and $\boldsymbol{P}_{\boldsymbol{o}}$ is the value of rainfall at the start of the series. The variation of precipitation $(\Delta \mathrm{P})$ due to the linear trend was calculated by the formula $\Delta P=a^{*}(D-1)$, where
$\boldsymbol{D}$ is the sample period. The magnitude of the variation was considered to be very strong when $\geq$ the standard deviation, strong when $\geq 50 \%$ of the standard deviation, and weak when $<50 \%$ of the standard deviation (Satyamurty et al. 2009). A positive slope indicates an increasing trend, while a negative value indicates a reduction in precipitation, with statistical significance assessed by the Mann-Kendall test.

Annual and seasonal trends were considered separately. A visual analysis of moving window (10 year) averages was used to detect patterns of partial changes in precipitation, and, when detected, the series were partitioned into sub-series, based on the visual analysis (Xu et al. 2003), and compared between the specific periods using the nonparametric Wilcoxon test (W). All analyses were performed using the free software R 2.13.0 (http://www.R-project.org).

\section{RESULTS}

The SLMM applied to the Landsat-5-TM images facilitated the detection of changes in the forest-savanna mosaic. Examining the types of vegetation present in the area
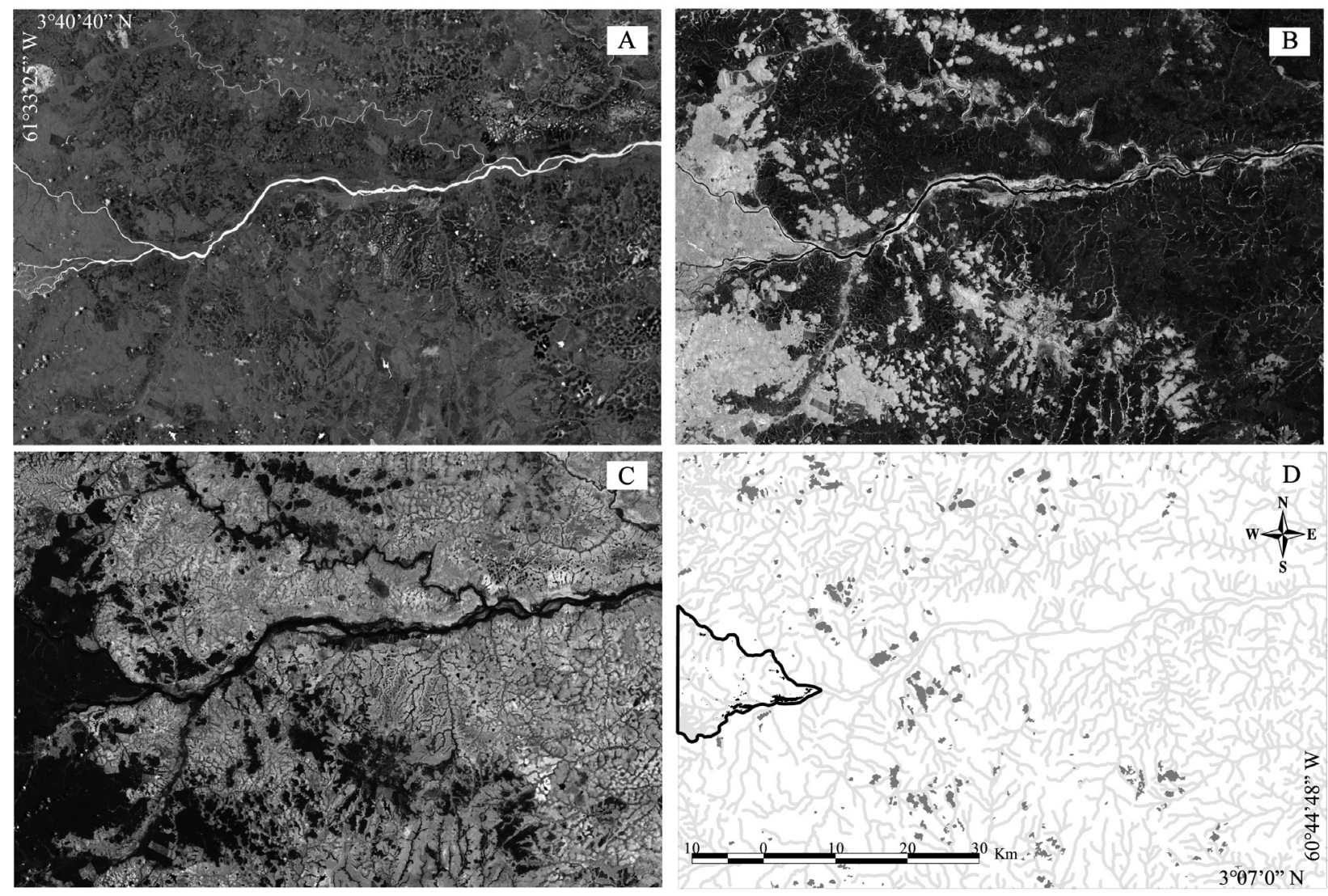

Figure 2 - A cropped scene 232/58 from 2006, with the study area highlighted by (A) shade, (B) vegetation, and (C) soil fraction images generated by the SLMM, and (D) the resulting thematic map, showing the savanna enclaves ( $\mathbf{\square})$ within the Maracá Ecological Station and the surrounding forest islands ( $\mathbf{\square})$. The thick black line shows the border of the Maracá Ecological Station. 
allowed for an improved characterization of the target areas, the distribution of which is shown in the thematic map of 2006, resulting from the classification by region of the fraction images generated by the mixture model (Figure 2).

\section{Dynamics in the protected area}

In the MES, a total of 96 savanna enclaves were detected, $19 \%$ of which appeared between the years 1994 ( $n=9$ ) and $2006(n=9)$. The size classes of the savanna enclaves produced an inverted "J" shaped distribution, with the vast majority (76\% in 2006) being smaller than 1 ha (Figure $3 \mathrm{~A})$. Only three enclaves presented an area larger than 20 ha and belonged to the hyperseasonal savanna class (verified by ground truthing). A significant difference in the distribution of size classes between 1986 and 2006 was observed $\left(\chi^{2}=13.98\right.$, $\mathrm{df}=2, \mathrm{p}<0.01)$, with an increase in the number of enclaves in the lower classes $\left(\leq 1 \mathrm{ha}, \chi^{2}=11.04, \mathrm{df}=1, \mathrm{p}<0.01\right)$ and $\mathrm{a}$ reduction in the largest size classes over the years (Figure $3 \mathrm{~A}$ ).

The total area of savanna varied significantly $(\mathrm{KW}=30.36$, $\mathrm{df}=2, \mathrm{p}<0.01$ ), from 746 ha in 1986, to 666 ha in 1994, and to 550 ha in 2006 , with a total reduction of $26 \%$ (196 ha) in the 20 years sampled, $10.7 \%$ in the first 8 years and $15.6 \%$ over the last 12 years, confirmed by the post-test for multiple comparisons $(p<0.05)$. The average rate of change for the savanna enclaves over the total sampling period (1986-2006) was -2.62 ha $( \pm 0.96 \mathrm{SE})$. Most enclaves $(88 \%)$ were reduced over time, with $48 \%$ of them belonging to the size class $\leq 1$ ha in 1986 . Only 3\% remained stable, and 9\% expanded (Figure $5)$. The rate of partial change was significantly greater $(\mathrm{V}=$

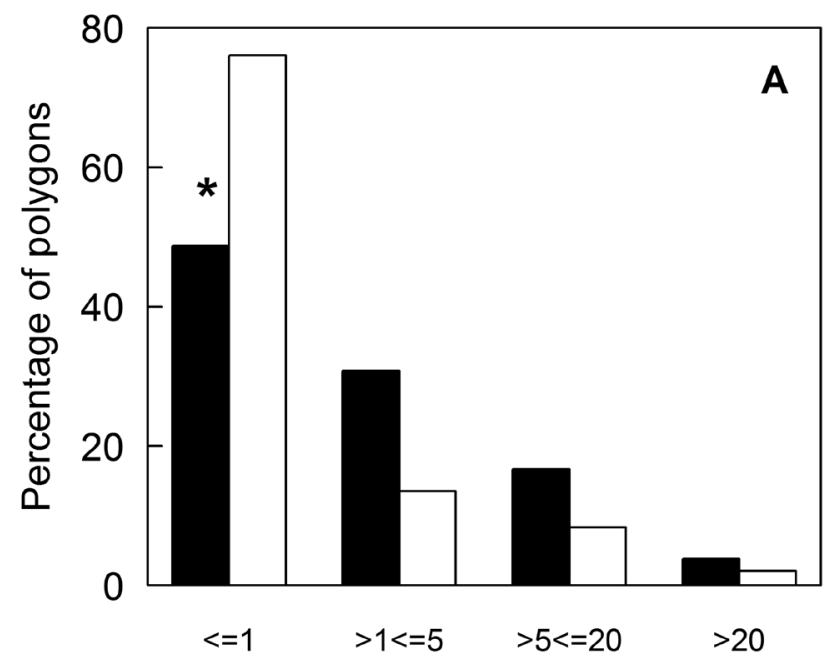

Size class (ha)

Figure 3 - The size class distributions of (A) the savanna enclaves in the Maracá Ecological Station between $1986(n=78)$ and $2006(n=96)$, and (B) of the forest islands surrounding the MES between $1986(n=219)$ and $2006(n=235)$. The asterisk represents a significant difference $(\alpha=0.05)$ between years in their respective classes.

2134, $\mathrm{p}<0.01$ ) during the period 1994-2006 compared to the first decade of sampling (Figure 4).

\section{Dynamics in the unprotected area}

A total of 314 forest islands were detected in the area surrounding the MES. 79 of these showed deforestation between 1997 and 2006 and were removed from the sample, totaling 235 forest islands evaluated. Of this total, 219 were already present in 1986 and 16 were new islands (7\% of the total) that appeared subsequently: 9 appeared between 1986 and 1994, and 7 between 1994 and 2006. The forest islands had an average size of 52 ha and followed an inverted "J" shaped size class distribution, with over $40 \%$ of them being smaller than 20 ha (Figure 3B). The variation in the size class distribution between years was not significant $\left(\chi^{2}=0.47, \mathrm{df}\right.$ $=3, \mathrm{p}=0.93$, Figure 3B).

There was no substantial change in the total area of the MES surrounding islands over the years $(\mathrm{KW}=1.54 \mathrm{df}$ $=2, \mathrm{p}=0.46)$. With a total starting area of 12,055 ha in 1986 , the forest islands suffered a small decline of 3.1\% in the first 8 years and a subsequent expansion of $4.5 \%$ in the second decade sampled, providing an overall (insignificant) expansion of $1.3 \%$ (162 ha) over 20 years. As a result of this stability, the average rate of change for the forest islands from 1986 to 2006 was almost zero $(0.004$ ha $\pm 0.90 \mathrm{SE})$, with approximately the same percentage of expanding (52.5\%) and contracting ( $47.5 \%$, Figure 5$)$ islands at a similar average rates of expansion and shrinkage over the 20 years (6.96 and -7.70 ha, respectively). However, a significant difference ( $V=15699$, $\mathrm{p}<0.001$ ) was detected between the rates of partial change for

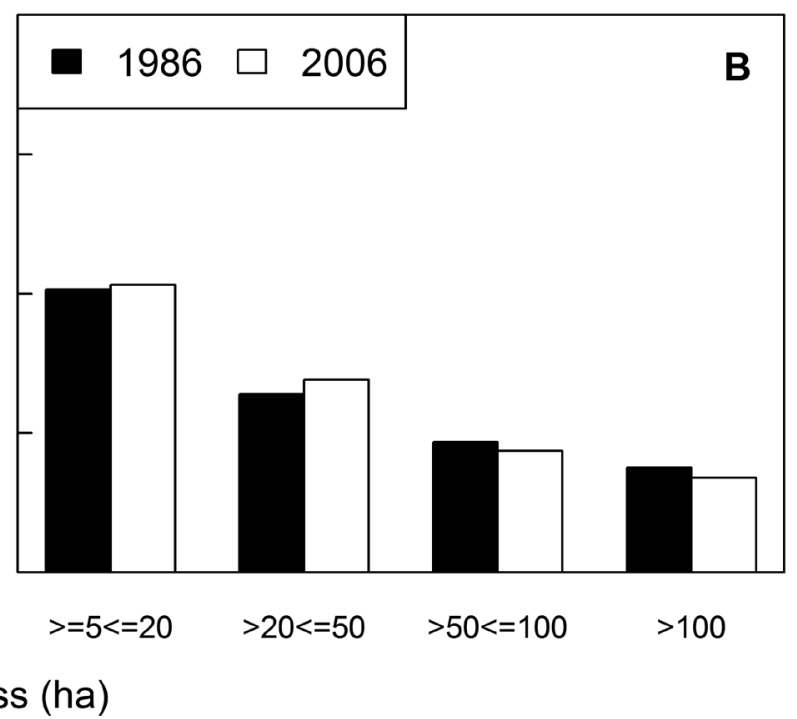




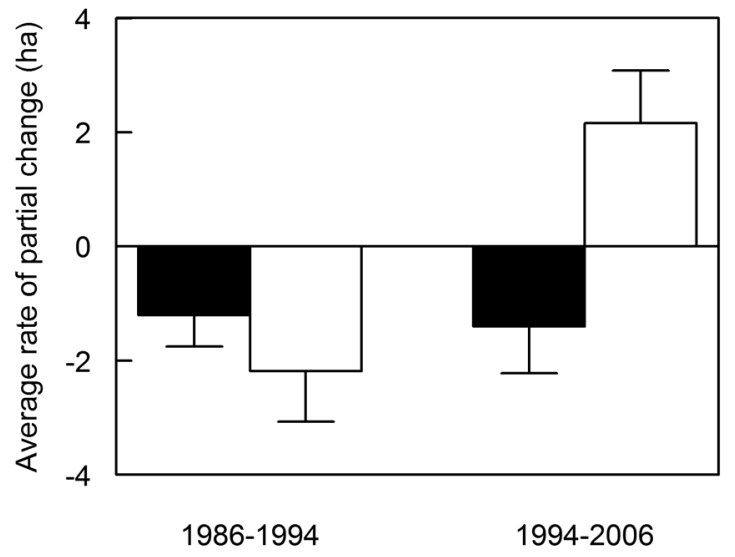

Figure 4 - The average rate of partial change for the savanna enclaves of Maracá Ecological Station (घ) and the surrounding forest islands ( $\square$ ). The error bars represent the standard errors.

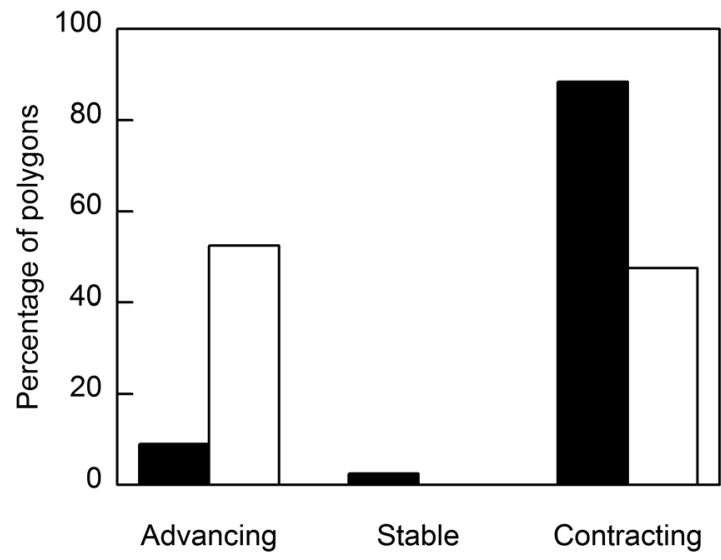

Figure 5 - The percentage of savanna enclaves ( $\square$ ) and surrounding forest islands ( $\square$ ) of the Maracá Ecological Station that are advancing, retracting or stable over the total sample period (1986-2006).

the two sampling periods, with an average of -2.18 ha from 1986 to 1994 and +2.16 ha from 1994 to 2006 (Figure 4).

\section{Rainfall dynamics}

The average annual rainfall measured in the climatological station of Boa Vista / RR was 1,657 mm over the last 98 years, with the average rainfall in the rainy season being approximately five times that of the dry season (Table 1). This marked climatic seasonality in rainfall was also observed in the MES (1986-2010), which showed a correlation with the data from Boa Vista $\left(r_{s}=0.62, p=0.004\right)$ but with values that were $30 \%$ greater (Table 1). The climatological data from the two stations were consistent with homogeneous dependence over time, based on the dual mass method $\left(\mathrm{R}^{2}=0.99\right)$.

Assessing the long-term climate trends, the Boa Vista station recorded an increase in total annual rainfall of 145 $\mathrm{mm} \mathrm{yr}^{-1}$ over 98 years, ranging from 1,579 $\mathrm{mm} \mathrm{yr}^{-1}$ in 1910 to $1,724 \mathrm{~mm} \mathrm{yr}^{-1}$ in 2008, based on a linear trend (Figure 6A). However, this positive trend was considered weak and not statistically significant, and the same pattern was found for the dry and wet seasons, independently (Table 1). Despite the lack of significance in the linear trend, inter-decadal oscillations were identified, based on 10-year moving averages, generating patterns with different precipitation regimes over the time series (Figure 6A).

A detailed analysis of the recent decades, from the time series available for the MES, confirmed the linear trend of increasing rainfall from 1986 to 2010 for both annual and seasonal data, which was significant only for the rainy season (Table 1, Figure 6B). During this season, the positive trend was considered to be very strong, with a variation of $457 \mathrm{~mm}$ season $^{-1}$ over 24 years. During the dry season, there was no significant variation in the sampled period (Table 1). Analyses of inter-decadal oscillations for the MES climatological station confirmed the same pattern shown by the more recent decades of the Boa Vista time series, with a downward trend in the precipitation regime from 1986 to 1994 (1,912 mm), followed by a significant increase (W = 30, p <0.05) from 1995 to 2010 (2,297 mm, Figure 6B).

\section{DISCUSSION}

Over the 20-year period evaluated, the small savanna enclaves in the MES forest matrix shrank, while the forest islands interspersed within the savanna matrix in its surroundings remained stable. The presence of disturbance events, such as fire, deforestation, and herbivory, identified as one of the primary ecological factors responsible for the occasional retraction of savanna-forest boundaries in the tropics, favors the occurrence of savanna species (House et al. 2003; Sankaran et al. 2004; Nepstad et al. 2008). The absence of these events in the MES since 1978 has led to the advance of forests into the savanna areas under the current climatic conditions, confirming that the conservation status positively affects the dynamics of the forest-savanna mosaics in the north region of the Brazilian Amazon. If these conditions remained constant, most of the savanna enclaves would disappear from the protected area within 153 years, as $98 \%$ of them are smaller than 20 ha. However, this vegetation would still persist for the next 4,000 years in the eastern region of the MES, where the presence of larger enclaves, composed primarily of hyperseasonal savanna, were detected.

Simulation models of environments in the absence of fire indicate that the trend of forests advancing on savanna occurs on a global scale (Bond et al. 2005). Specifically, for the transition areas of South America, studies suggest that, under the current climate conditions and in the absence of fire, tropical forests should expand linearly, by approximately 

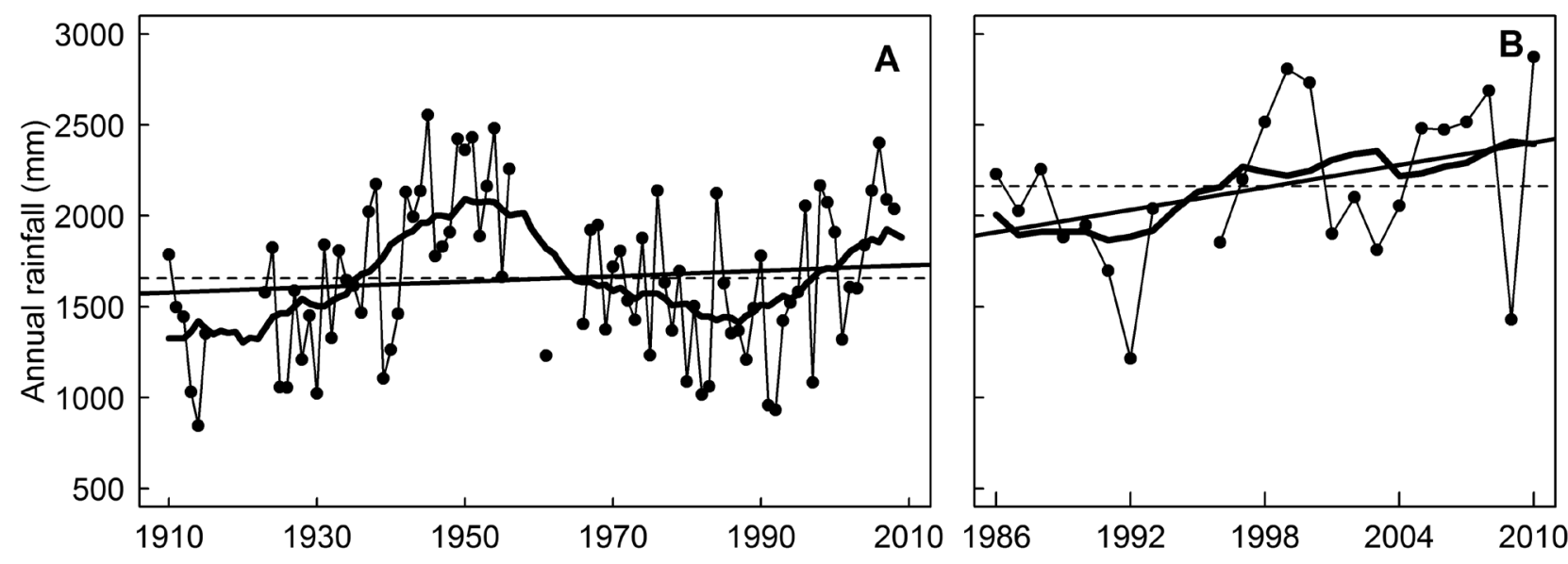

Figure 6 - The annual rainfall in (A) Boa Vista, over the last 98 years, and (B) in the Maracá Ecological Station, over the past 24 years $(-\bullet-)$. The long-term linear trend line, based on the equation $\left(P=P_{0}+\right.$ at) $(-)$. The average rainfall over the years sampled (---). The 10-year moving averages $(-)$.

$200 \mathrm{~km}$ in 1000 years, onto the savanna areas currently observed (Hirota et al. 2010). Despite this trend, indicated by simulations, empirical data that support these models are scarce, and the present study aimed to fill this gap. Our results confirm the evidence presented by previous studies of the local expansion of forests over grasslands within the MES, based solely on the floristic composition and soil analyses from specific sites (Furley and Ratter 1990; Thompson et al. 1992a).

The increase in human activities, to meet the growing demand for agricultural areas and livestock practice, has promoted changes in both land use and cover, leading to changes in the forest areas of the Amazon Basin (Davidson et al. 2012). However, the forest islands in the disturbed areas surrounding the MES remained stable. This relative stability of the limits in the medium term corroborates other studies conducted in unprotected transition areas in the state of Roraima, based on analyses of carbon isotopes (Desjardins et al. 1996) and soil fertility (Eden and McGregor 1992), and in areas of shifting cultivation (slash and burn) around Rupununi in the south of Guyana, with forests advancing only in areas of abandoned agriculture and reduced incidence of fire (Eden 1986).

The unprotected areas surrounding the MES were shown to be a dynamic system, involving changes of boundaries in opposite directions, with the apparent stability generated by equivalent proportions of the forest islands contracting and expanding. This variation may be related to the spatial distribution of disturbances, focusing on areas of high anthropogenic pressure, as in the vicinity of cleared areas, such as roads and settlements, which are more susceptible to the presence of recurrent fire. However, this pattern should be further investigated.
As the transition of forest-savanna boundaries results from a complex relationship between different factors that vary simultaneously, the difficulty of isolating or experimentally manipulating these factors compromises a detailed assessment of their impacts on spatial and temporal scales in ecosystem dynamics (House et al. 2003). However, modeling techniques have proven useful for investigating the causes of these changes and suggest that precipitation and soil properties are the primary causes of the occurrence of African savannas, whereas fire and herbivory are secondary factors (Higgins et al. 2010). In these models, in areas with average annual rainfall $>1,200$ $\mathrm{mm}$, fire becomes necessary for the persistence of the savannas, whereas, along a reduced precipitation gradient system, stability occurs even in the absence of fire. This principle appears to apply also to the areas of the forest-savanna mosaics in northern Amazon, where the average rainfall is relatively high (approximately 2,000 $\mathrm{mm}$ ), causing the advancement of forest systems, while the stability of unprotected forest islands is associated with the occurrence of fire.

Rainfall variations were shown to influence the dynamics of the forest-savanna areas assessed in the present study. In the protected area, the shrinkage rates of savannas were intensified during periods of increased precipitation. However, a 20\% increase in precipitation led to a difference of only $8 \%$ in the reduction of savanna between wet and dry periods. This relationship must therefore be considered with caution in these areas, as the variation in vegetation may reflect, in part, the recovery of past disturbances in the MES, before its transformation into a conservation unit, which occurred only 8 years before the beginning of the study sampling period. In the unprotected area, the influence of climate was more visible because it alters the direction of the mosaics 
Table 1 - Annual and seasonal rainfall and the long-term linear trend recorded at the meteorological stations located at Boa Vista (1910-2008) and at the Maracá Ecological Station (1986-2010). Units are $\mathrm{mm} \mathrm{yr}^{-1}$ or mm season ${ }^{-1} . \mathrm{a}=$ slope, $\mathrm{D}=$ total sample period in years, $\Delta \mathrm{P}=$ Variation in precipitation, and $p=$ statistical significance $(\alpha=0.05)$.

\begin{tabular}{|c|c|c|c|c|c|c|c|}
\hline Location & Season & $\begin{array}{l}\text { Annual precipitation } \\
\text { (mean } \pm \text { SD) }\end{array}$ & $\begin{array}{l}\text { Linear trend } \\
\left(\mathrm{P}=\mathrm{P}_{0}+\text { at }\right)\end{array}$ & Period (D) & $\Delta \mathbf{P}$ & $\begin{array}{l}\text { Mann-Kendall } \\
\text { (tau) }\end{array}$ & $p$ \\
\hline \multirow{3}{*}{ Boa Vista } & Annual & $1657 \pm 418$ & $1579+1.5 t$ & \multirow{3}{*}{98} & 145 & 0.08 & 0.26 \\
\hline & Rainy & $1386 \pm 344$ & $1346+0.8 t$ & & 75 & 0.05 & 0.49 \\
\hline & Dry & $271 \pm 132$ & $238+0.6 t$ & & 61 & 0.09 & 0.23 \\
\hline \multirow{3}{*}{ MES } & Annual & $2163 \pm 431$ & $1920+20.5 t$ & \multirow{3}{*}{24} & 472 & 0.24 & 0.11 \\
\hline & Rainy & $1693 \pm 314$ & $1448+19.9 t$ & & 457 & 0.35 & 0.02 \\
\hline & Dry & $470 \pm 211$ & $462+0.7 t$ & & 15 & 0.00 & 1.00 \\
\hline
\end{tabular}

dynamics. Despite the advancement of forests on savannas predominating during the wetter period, even in the presence of disturbances, the expansion of the savanna prevailed in periods of reduced rainfall, as predicted by Oyama and Nobre (2003) for this region.

The long-term variability in rainfall is the result of complex interactions influenced by the effects of deforestation, changes in $\mathrm{CO}_{2}$ levels in the atmosphere, and the surface temperature of the oceans, among other factors (Costa and Foley 2000). The linear trend of precipitation shows differences for the Amazon basin as a whole, especially at the regional level (Marengo 2004; Espinoza et al. 2009; Satyamurty et al. 2009). This trend was positive and significant only for the rainy seasons of the MES from 1986 and corroborated the model suggested by Espinoza et al. (2009) for the north region of the Amazon basin; however, this trend was sufficient to encourage the retraction of savannas in the conservation unit. The intensification of the dry season is recognized as a limiting factor for the advancement of forests, but this was not a limiting factor in the MES, as the precipitation regime during this season remained constant over the years.

However, more important than the unidirectional trend was the inter-decadal signal, with alternations between wet and dry periods, which has direct effects on the structure and dynamics of tropical forests (Malhi and Wright 2004). The productivity and mortality of forest species respond almost immediately to short-medium term climate trends (Botta et al. 2002; Nepstad et al. 2007; Phillips et al. 2010). These effects were also observed in the dynamics of the forest-savanna mosaics in the region surrounding the MES, presenting evidence of responses primarily to climate and secondarily to the presence of disturbances (e.g., fire) during the 20-year period of this study (1986 - 2006).

The impact of global climate change, driven by the acceleration of greenhouse gas emissions and changes in land use, is expected to occur due to the mechanisms of vegetationclimate interaction. Due to its sensibility to climate, these changes may cause the displacement of the Amazon forests, expanding areas of forest-savanna transition in the near future. As the first signs of climate impacts should be detected in ecotones (Malhi et al. 2008), the dynamics of forest-savanna mosaics in areas of climatic transition with no protection status should be primarily affected. Carbon stocks and flows are likely to be especially affected, as these ecosystems play an important role in stocking and cycling large amounts of carbon in the biomass and at the interface with the atmosphere. As climatic factors are considered to be one of the primary causes of alterations in the limits for this forest-savanna transition area in northern Amazon, the success of proposals for the conservation of these environments depends not only on the maintenance of existing conservation units but also on the mitigation of global climate change to reduce the emission of greenhouse gases, thus avoiding the loss of forests due to climate variability.

\section{CONCLUSIONS}

Both conservation status and rainfall variations were shown to influence the dynamics of the forest-savanna mosaics in the north region of the Brazilian Amazon, which were mediated primarily by the climate and secondarily by the presence of disturbances. Conservation strategies of the MES, associated with the relative increase in precipitation of the rainy season over the last 20 years, favored the advancement

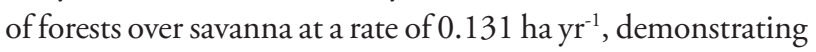
the importance of the conservation unit in maintaining environmental services. The scenario outside of the protected area indicated the relative stability of mosaics, guaranteed by the interaction between climate variability and the presence of disturbances. The predominance of advancing forest in years with increased precipitation (1994-2006), even in unprotected areas, demonstrated the dominance of climate effects above the effects of disturbances. The expansion of savanna in these areas, during periods of reduced precipitation (1986-1994), indicates that, the trend of increased frequency of climatic events, such as drought, currently predicted by climate models for the region could affect the extent and direction of future changes in the forest limits surrounding the MES, jeopardizing the local biodiversity and environmental services. 


\section{ACKNOWLEDGEMENTS}

We thank Reinaldo Barbosa, Bruce Nelson, Yosio Shimabukuro, Marcos Heil Costa, Ítalo Mourthé, and the three anonymous reviewers for their valuable suggestions and Valdete Duarte for image processing support. We appreciate the logistical support of the Instituto Chico Mendes de Conservaçáo da Biodiversidade, Instituto Nacional de Pesquisas da Amazônia (núcleo Roraima), the Maracá team, and the surrounding farmers. We also would like to thank Serviço Geológico do Brasil and Instituto Nacional de Meteorologia for the provision of climatic data. This work was funded by Grupo Boticário de Proteção à Natureza (Projeto 0889_20102) and Conselho Nacional de Desenvolvimento Científico e Tecnológico.

\section{REFERENCES}

Almeida-Filho, R.; Shimabukuro, Y.E. 2002. Digital processing of a Landsat-TM time series for mapping and monitoring degraded areas caused by independent gold miners, Roraima State, Brazilian Amazon. Remote Sensing of Environment, 79: 42-50.

Anderson, L.O.; Aragão, L.E.O.C.; Lima, A.; Shimabukuro, Y.E. 2005. Detecção de cicatrizes de áreas queimadas baseada no modelo linear de mistura espectral e imagens índice de vegetação utilizando dados multitemporais do sensor MODIS/TERRA no estado do Mato Grosso, Amazônia brasileira. Acta Amazonica, 35: $445-456$.

Bond, W.J.; Woodward, F.I.; Midgley, G.F. 2005. The global distribution of ecosystems in a world without fire. New Phytologist, 165: 525-538.

Botta, A.; Ramankutty, N.; Foley, J.A. 2002. Long-term variations of climate and carbon fluxes over the Amazon basin. Geophysical Research Letters, 29: 1319.

Costa, M.H.; Foley, J.A. 2000. Combined effects of deforestation and doubled atmospheric $\mathrm{CO}_{2}$ concentrations on the climate of Amazonia. Journal of Climate, 13: 18-34.

Davidson, E.A.; Araújo, A.C.; Artaxo, P.; Balch, J.K.; Brown, I.F.; Bustamante, M.M.C.; Coe, M.T.; DeFries, R.S.; Keller, M.; Longo, M.; Munger, J.W.; Schroeder, W.; Soares-Filho, B.S.; Souza, C.M.; Wofsy, S.C. 2012. The Amazon basin in transition. Nature, 481: 321-328.

Desjardins, T.; Carneiro Filho, A.; Mariotti, A.; Chauvel, A.; Girardin, C. 1996. Changes of the forest-savanna boundary in Brazilian Amazonia during the Holocene revealed by stable isotope ratios of soil organic carbon. Oecologia, 108: 749-756.

Eden, M.J. 1986. Monitoring indigenous shifiting cultivation in forest areas of southwest Guyana using aerial photography and Landsat. In: Eden, M.J.; Parry, J.T. (Eds.). Remote Sensing and Tropical Land Management. John Wiley, Chichester, p. 255-277.

Eden, M.J.; McGregor, D.F.M. 1992. Dynamics of the forest-savanna boundary in the Rio Branco-Rupununi region of northern Amazonia. In: Furley, P.A.; Proctor, J.; Ratter, J.A. (Eds.). The nature and dynamics of forest-savanna boundaries. Chapman \& Hall, London, p. 77-89.
Espinoza, J.C.; Ronchail, J.; Guyot, J.L.; Cochonneau, G.; Naziano, F.; Lavado, W.; Oliveira, E.; Pombosa, R.; Vauchel, P. 2009. Spatio-temporal rainfall variability in the Amazon basin countries (Brazil, Peru, Bolivia, Colombia, and Ecuador). International Journal of Climatology, 29: 1574-1594.

Ferreira, M.E.; Ferreira, L.G.; Sano, E.E.; Shimabukuro, Y.E. 2007. Spectral linear mixture modelling approaches for land cover mapping of tropical savanna areas in Brazil. International Journal of Remote Sensing, 28: 413-429.

Furley, P.A.; Ratter, J.A. 1990. Pedological and botanical variations across the forest-savanna transition on Maracá Island. The Geographical Journal, 156: 251-266.

Furley, P.A.; Dargie, T.; Place, C.J. 1994. Remote sensing and the establishment of a geographic information system for resource management on and around Maracá Island. In: Hemmings, J. (Ed.). The rainforest edge: plant and soil ecology of Maracá Island, Brazil. Manchester University Press, New York, p. 115-134.

Haertel, V.; Shimabukuro, Y.E.; Almeida-Filho, R. 2004. Fraction images in multitemporal change detection. International Journal of Remote Sensing, 25: 5473-5489.

Higgins, S.I.; Scheiter, S.; Sankaran, M. 2010. The stability of African savannas: insights from the indirect estimation of the parameters of a dynamic model. Ecology, 91: 1682-1692.

Hirota, M.; Nobre, C.; Oyama, M.D.; Bustamante, M.M.C. 2010. The climatic sensitivity of the forest, savanna and forest-savanna transition in tropical South America. New Phytologist, 187: 707-719.

House, J.I.; Archer, S.; Breshears, D.D.; Scholes, R.J. 2003. Conundrums in mixed woody-herbaceous plant systems. Journal of Biogeography, 30: 1763-1777.

Lu, D.; Moran, E.; Batistella, M. 2003. Linear mixture model applied to Amazonian vegetation classification. Remote Sensing of Environment, 87: 456-469.

Malhi, Y.; Wright, J. 2004. Spatial patterns and recent trends in the climate of tropical rainforest regions. Philosophical Transactions of the Royal Society B: Biological Sciences, 359: 311-329.

Malhi, Y.; Roberts, J.T.; Betts, R.A.; Killeen, T.J.; Li, W.; Nobre, C.A. 2008. Climate change, deforestation, and the fate of the Amazon. Science, 319: 169-172.

Marengo, J.A. 2004. Interdecadal variability and trends of rainfall across the Amazon basin. Theoretical and Applied Climatology, 78: 79-96.

Nepstad, D.C.; Stickler, C.M.; Soares-Filho, B.; Merry, F. 2008. Interactions among Amazon land use, forests and climate: prospects for a near-term forest tipping point. Philosophical Transactions of the Royal Society B: Biological Sciences, 363: 1737-1746.

Nepstad, D.C.; Tohver, I.M.; Ray, D.; Moutinho, P.; Cardinot, G. 2007. Mortality of large trees and lianas following experimental drought in an Amazon forest. Ecology, 88: 2259-2269.

Oyama, M.D.; Nobre, C.A. 2003. A new climate-vegetation equilibrium state for Tropical South America. Geophysical Research Letters, 30: 2199. 
Phillips, O.L.; van der Heijden, G.; Lewis, S.L.; López-González, G.; et al. 2010. Drought-mortality relationships for tropical forests. New Phytologist, 187: 631-646.

Salazar, L.F.; Nobre, C.A.; Oyama, M.D. 2007. Climate change consequences on the biome distribution in tropical South America. Geophysical Research Letters, 34: L09708.

Sankaran, M.; Ratnam, J.; Hanan, N.P. 2004. Tree-grass coexistence in savannas revisited - insights from an examination of assumptions and mechanisms invoked in existing models. Ecology Letters, 7: 480-490.

Satyamurty, P.; Castro, A.A.; Tota, J.; Gularte, L.E.S.; Manzi, A.O. 2009. Rainfall trends in the Brazilian Amazon Basin in the past eight decades. Theoretical and Applied Climatology, 99: 139-148.

Shimabukuro, Y.E.; Duarte, V.; Arai, E.; Freitas, R.M.; Martini, P.R.; Lima, A. 2010. Monitoring land cover in Acre State, western Brazilian Amazonia, using multitemporal remote sensing data. International Journal of Image and Data Fusion, 1: 325-335.

Soares-Filho, B.; Moutinho, P.; Nepstad, D.; Anderson, A.; Rodrigues, H.; Garcia, R.; Dietzsch, L.; Merry, F.; Bowman, M.; Hissa, L.; Silvestrini, R.; Maretti, C. 2010. Role of Brazilian
Amazon protected areas in climate change mitigation. Proceedings of the National Academy of Sciences, 107: 10821-10826.

Sternberg, L.D.L. 2001. Savanna-forest hysteresis in the tropics. Global Ecology and Biogeography, 10: 369-378.

Thompson, J.; Proctor, J.; Viana, V.; Ratter, J.A.; Scott, D.A. 1992a. The forest-savanna boundary on Maracá Island, Roraima, Brazil: an investigation of two contrasting transects. In: Furley, P.A.; Proctor, J.; Ratter, J.A. (Eds.). The nature and dynamics of forestsavanna boundaries. Chapman \& Hall, London, p. 367-392.

Thompson, J.; Proctor, J.; Viana, V.; Milliken, W.; Ratter, J.A.; Scott, D.A. 1992b. Ecological studies on a lowland evergreen rain forest on Maraca Island, Roraima, Brazil. I. Physical environment, forest structure and leaf chemistry. The Journal of Ecology, 80: 689-703.

Xu, Z.X.; Takeuchi, K.; Ishidaira, H. 2003. Monotonic trend and step changes in Japanese precipitation. Journal of Hydrology, 279: $144-150$.

Recebido em 09/12/2012

Aceito em 10/06/2013 